\title{
Financial Development, Institutions and Economic Growth in WAEMU Countries
}

\author{
Abdou Khadre Dieng ${ }^{1} \&$ Abdoulaye Camara ${ }^{2}$ \\ ${ }^{1} \mathrm{PhD}$, LAPD, Faculty of Economics and Management, Cheikh Anta Diop University of Dakar, Senegal \\ ${ }^{2}$ PhD Student, Finance for Development Laboratory, Cheikh Anta Diop University of Dakar, Senegal \\ Correspondence: Abdou Khadre Dieng, PhD, LAPD, Faculty of Economics and Management, Cheikh Anta Diop \\ University of Dakar, Senegal. E-mail: abdoukhadre6.dieng@ucad.edu.sn
}

Received: June 2, 2021

Accepted: July 4, 2021

Online Published: July 18, 2021

doi:10.5539/ijef.v13n8p40

URL: https://doi.org/10.5539/ijef.v13n8p40

\begin{abstract}
This paper aims to study the impact of financial development and the institutional environment on economic growth in the countries of the WAEMU (West Africa Economic and Monetary Union) zone. We used a standard growth model like Eggoh (2010) with a cointegration technique on panel data. We used the 2017 World Bank database (World Bank data, 2017).

The results showed that money supply to GDP (M2/GDP), domestic bank credit to GDP (CB/GDP) and regulatory quality $(\mathrm{QR})$ have a positive and significant impact on long-term economic growth. However, the positive effect of respect for law and order is not significant.
\end{abstract}

Keywords: financial development, economic growth, institutions, WAEMU, FMOLS

\section{Introduction}

Since Schumpeter's pioneering work (1912), the theme of financial development has gained renewed interest in economic theory. The relationship between financial development and economic growth has been the subject of several research works with mixed results. Schumpeter (1912) defended the idea that financial intermediaries invest in innovative wealth-creating projects. Following Schumpeter (1912), researchers have addressed the issue and support a beneficial effect of financial development on economic growth (Gurley \& Shaw, 1955; Goldsmith, 1969; King, 1993; Hassan, Sanchez, \& Yu, 2011; Muye \& Muye, 2017). However, other authors concluded that financial development follows economic growth and one of the most prominent of these is Robinson (1952). Similarly, authors Odhiamb (2004) and Mckibbin (2007) believe that a financial system can only positively impact economic growth if it reaches a certain level of development. This shows that there has long been a difference in approach between theorists. In this paper, we adopt Levine's (2005) approach, which conceives of financial development as the process by which financial instruments, markets and intermediaries improve the processing of information, the implementation of contracts and the execution of transactions, thus enabling the financial system to better perform the functions which have been allotted to it, namely, the facilitation of trade in goods and services, the mobilization and collection of savings, the production of information on potential investments, and the allocation of savings, distribution, diversification and risk management, monitoring of investments in execution and control of governance.

In addition, recent research has emphasized the importance of institutional development in the relationship between financial development and economic growth (Kim et al., 2010; Cezar, 2012; Sabir et al., 2019). By referring to certain indicators of the quality of institutions, some research works have managed to show that an efficient institutional framework promotes the most productive investments, the development of financial intermediation and, subsequently, economic growth (Wurgle, 2000; Arestis et al., 2002; Gani \& Ngassam, 2008, etc.). Indeed, institutions that operate in the market promote more efficient resource mobilization (Muye \& Muye, 2017) and thus appear as an important variable in the relationship between financial development and economic growth. A set of political institutions, including ownership, rights, law-and-order, voice, and accountability, as well as economic institutions are essential for achieving sustainable economic growth (Sabir et al., 2019).

Moreover, in recent years we have noted vigorous economic growth in the WAEMU countries, which is a harmonized and integrated economic space made up of eight coastal and Sahelian Countries, namely Benin, 
Burkina Faso, Côte d'Ivoire, Guinea Bissau, Mali, Niger, Senegal, and Togo. Within this space, regional GDP growth averaged $6.1 \%$ in 2019 compared to $6.4 \%$ in 2018, thanks to the current investments in infrastructure, strong private consumption, and favorable agricultural campaigns. Inflation is relatively well under control in this zone thanks to the exchange rate peg and the positive development of trading terms. In addition, the financial system is weakly developed, characterized by a shallow and segmented interbank market, which impedes access to private sector financing. The segmented nature of the banking sector stems from the fact that institutions with excess liquidity are subsidiaries of large international banking groups which did not participate in the interbank market, while local banks generally have liquidity needs. The authorities are in the process of setting up prudential limits in line with international standards and best practices, but also in avoiding regulatory laxity. Moreover, the policies implemented to stimulate and maintain the growth dynamic are strongly oriented towards the expansion of an efficient financial system within the WAEMU area.

In this wake, and in view of the mixed literature on the subject, we ask ourselves the following question: what is the impact of financial development and the institutional environment on economic growth in the WAEMU countries?

The answer to this question will enable a better design of policies aimed at expanding the financial system within a regulatory and institutional framework conducive to better economic growth in the region.

Accordingly, the objective of this paper is to measure the impact of financial development and the institutional environment on economic growth in the WAEMU countries.

In this research, a standard growth model is used following the example of Eggoh (2010) with a cointegration technique based on panel data. We used the World Bank database of 2017 (World Bank data, 2017). The remainder of this article is organized in four sections. Section 2 is devoted to the literature review. The third section discusses the methodology used. The econometric estimates and results are presented in the fourth section and the fifth section is devoted to the conclusion and the implications of the economic policy.

\section{Literature Review}

The financial system refers to the set of institutions, instruments and mechanisms that link economic agents seeking financing, who are qualified as agents in need of financing, and those willing to invest their funds or agents with financing capacity. Since the work of Raymond Goldsmith (1969), Schumpeter (1912) and Gurley \& Shaw (1955), the analysis of the role of the financial system in the growth process has been reinforced by the development of endogenous growth theoretical models that incorporate the financial sphere. It is recognized that capital accumulation and technological change are not the only factors that explain differences in the level of development between countries. Using gross domestic product per capita as a measure of the development of economic activity, many economists argue that differences at the global level could be explained by the quality of the financial system and institutional development.

Theoretical work that considers financial development in endogenous growth models generally establishes a positive effect between these two variables through different channels. Bencivenga and Smith (1991), concluded that the emergence of financial intermediaries changes the structure of savings by directing liquid resources to illiquid long-term investments. According to Pagano (1993), financial sector development affects long-term growth because it increases the amount of savings for investment. Diversification and risk sharing were identified by King and Levine (1993a) and Acemoglu and Zilibotti (1997) to highlight the positive effect of the financial sector on growth. Finally, the reduction of imperfections resulting from financial development was highlighted by Bencivenga and Smith (1998), Zilibotti (1994), and Blackburn and Hung (1998).

Numerous empirical works have attempted to identify the potential sources of the non-linearity between financial development and economic growth. Huang and Lin (2009) detected non-linearity from the database of Levine \& al. (2000) and showed that the positive effect of financial development on growth is higher in low-income countries than in rich countries. Other results showed that the non-linearity of this relationship is conditional on income level (Deidda \& Fattouh, 2002; Rioja \& Valev, 2004). However, the results of the latter were contrary to those of Huang and Lin (2009) since they found a non-significant relationship between financial development and growth in low-income countries, whereas this relationship was positive and robust in high-income countries. Moreover, policymakers and researchers are increasingly considering the important role of institutions in the relationship between financial development and economic growth (Acemoglu \& Johnson, 2005; Chauffour, 2011; Nawaz, 2015). Demetriades and Law (2006) concluded that financial development would have a favorable effect on growth when institutions are sound, whereas this correlation would disappear in countries with unfavorable institutional settings. For their part, Kim et al. (2010) considered that institutions operating in the financial market are capable of providing information on risk diversification and profitable 
activities and can promote resource mobilization. For example, Acemoglu and Johnson (2005) who found that institutions that affect sectors of the economy have an important direct effect on financial development. They also showed that property rights and contracting institutions are important determinants of financial development. Chauffour (2011) argued that institutions, as measured by economic freedom and civil and political liberties, justify the fact that some countries achieve and maintain better economic growth than others. Baier et al. (2012) noted that in the immediate aftermath of a crisis, there is typically a decline in economic freedom that results from increased regulation and leads to slower economic growth in the future. Nawaz (2015) also found that institutions play a greater role in determining economic growth in developed countries relative to developing economies. Law et al. (2013) believed that the link between financial development and economic growth was highly dependent on institutional quality, thus supporting the idea that better finance is needed to promote economic growth. For their part, Barajas et al. (2013) noted that the beneficial effect of financial development on economic growth varies across countries; low-income countries benefit less because their regulatory and supervisory systems are less developed. With Gazdar and Cherif (2015) showing that financing is more likely to support economic growth in MENA countries with a strong institutional environment.

For their part, Le et al. (2016), basing on a sample of Asian countries, found that better governance and institutional quality fostered financial sector development in developing economies. Similarly, Muye and Muye (2017), looking at various regional blocs, found a strong relationship between financial development and institutions. Overall, these different research findings seem to confirm the importance of institutions in the relationship between financial development and economic growth. Benali (2020) concludes that the effect of financial development on economic growth depends on institutional quality. This means that a better institutional environment allows an economy to explore the benefits of financial sector reforms in promoting economic growth. In the same launched, EBO'OH NTJEN and NEBA (2021) specify that the economies of sub-Saharan Africa must improve the quality of their political institutions, in order to lower the quality threshold of economic institutions likely to promote an best financial development impact over growth.

\section{Methodology}

\subsection{Model Presentation}

Testing empirical links between finance, institutions and economic growth using linear growth equations has become a common practice. In this paper we drew inspiration from the models of King and Levine (1993a, b), Levine and Zervos (1998), and Eggoh (2010). The cointegration technique on panel data was used. The standard growth model used is as follows:

$$
\ln y_{i t}=\alpha_{0 i}+\alpha_{1 i} \ln F_{i t}+\alpha_{2 i} \operatorname{lnIns}_{i t}+\alpha_{3 i} c g_{i t}+\alpha_{4 i} t i n f_{i t}+\varepsilon_{i t}
$$

In this model, $\mathbf{y}$ represents the GDP per capita (constant GDP ppp 2011) of country $\mathbf{i}$ at time $\mathbf{t}, \mathbf{F}$ represents the financial development indicators, namely money supply in relation to GDP (M2/GDP), domestic bank credit in relation to GDP (CB/GDP), domestic credit to the private sector in relation to GDP (CP/GDP), Ins represents the institutional variables, namely the regulation quality $\mathrm{QR}$, and compliance with law-and-order by economic agents RL, Cg represents the claims on the government relative to GDP, and tinf measures the level of inflation in the space under consideration. We have $\varepsilon$ which represents the error term. This equation is considered to reflect a long-term equilibrium relationship between the selected variables if they are cointegrated with the presence of a cointegration equation.

\subsection{Selection of Variables and Data Source}

Economic growth is measured by growth in GDP per capita. With respects to financial development, many indicators are used to approximate it, and the most used approach in the literature is the ratio of broad money supply, M2, to nominal GDP or GNP (we find this indicator in McKinnon (1973); King and Levine (1993); Beck et al. (1999); Levine et al. (2000). This indicator is a measure of financial depth, it highlights the fact that the financial system (measured by M2/GDP) is related to the rate of growth through the channels of "investment volume" and "investment efficiency. However, even though it is highly prized in the literature, this ratio has a limitation. Indeed, it may better reflect the monetization of transactions than the degree of intermediation because it captures the increase in the amount of money in circulation for transaction purposes more than it does the increase in the volume of bank deposits. For these reasons, two alternative indicators are used to characterize financial development. First, domestic bank credit as a percentage of GDP, which includes all credit allocated to the different sectors of the economy on a gross basis except for credit to the government, which is net. It can give an indication of the extent to which the banking sector plays a role in the WAEMU countries. Notwithstanding its relevance, to better analyze the composition of domestic credit, a third ratio is calculated, which is the domestic credit granted to the private sector relative to GDP. The latter measures the activity of financial 
intermediaries in terms of one of their main functions: channeling savings to investors. Its main advantage is that it excludes credit to the public sector and focuses on the role of financial intermediaries in transmitting funds to market participants. Thus, it is the definition of financial intermediation that comes closest to the level and efficiency of investment and thus to economic growth. It is a good indicator of the level of financial development in developing countries, except that it does not consider credits obtained outside the banking system or credits from firms that borrow directly from abroad. It was used for the first time by Levine and Zervos (1998) and the second time by Beck et al. (1999). Thanks to their complementarity, these three indicators used together should make it possible to approach the financial development of the WAEMU countries.

For the institutional variables, we used QR and RL. The RL variable which encompasses compliance with law-and-order, measures the power and independence of the judiciary and the quality of law enforcement (Gries \& Meierrieks, 2009). It also measures agents' level of confidence in and compliance with the rules of society, including perceptions of the number of crimes, the efficiency and predictability of the judicial system, and the enforceability of contracts (Beyera, 2013). Good regulatory quality (QR) is necessary to enable the conclusion and enforcement of fair contracts between banks on the one hand, and the depositors and the deposit insurance institution on the other (Jacquet \& Pollin, 2007).

In this work, we used the World Bank's 2017 database (World Bank data, 2017). The study covered the period 2002-2015 and focuses on a panel of the eight WAEMU countries.

\subsection{Analysis of Descriptive Statistics}

The purpose of this subsection is to highlight the statistical relationships between the main variables used in the empirical model and economic growth in the sample countries. The following table presents GDP/capita statistics for all eight sample countries.

Table 1. GDP/capita and M2/GDP ratio in the WAEMU countries from 2002 to 2015

\begin{tabular}{ccccccc}
\hline \multirow{2}{*}{ Countries } & \multicolumn{3}{c}{ M2/GDP } & \multicolumn{3}{c}{ GDP/capita } \\
\cline { 2 - 7 } & Minimum & Average & Maximum & Minimum & Average & Maximum \\
\hline Benin & 21.04 & 31.70 & 43.34 & 1693.51 & 1772.83 & 1942.26 \\
Burkina Faso & 18.02 & 25.54 & 36.71 & 1129.94 & 1358.47 & 1592.92 \\
Ivory Coast & 19.78 & 29.70 & 40.26 & 2546.91 & 2780.43 & 3300.07 \\
Guinea Bissau & 11.01 & 26.46 & 49.55 & 1227.69 & 1297.42 & 1416.31 \\
Mali & 22.89 & 25.59 & 28.89 & 1628.16 & 1776.31 & 1904.86 \\
Niger & 9.00 & 17.77 & 27.22 & 765.08 & 814.86 & 901.76 \\
Senegal & 26.10 & 36.69 & 48.42 & 1910.32 & 2109.05 & 2273.62 \\
Togo & 22.77 & 38.06 & 55.58 & 1202.65 & 1245.24 & 1371.56 \\
WAEMU & 9.00 & 28.94 & 55.58 & 765.08 & 1644.33 & 3300.07 \\
\hline
\end{tabular}

Source: Authors' calculations based on World Bank data, 2017.

The results show, on the one hand, that Ivory Coast and Senegal achieved the highest GDP per capita during the study period, with 3300.07 and 2273.62 (in ppp) respectively, recorded in 2015, while Niger achieved the lowest GDP per capita estimated at 765.08 (in ppp) recorded in 2004. On average over the period, Ivory Coast and Senegal recorded the highest values with 2780.43 and 2109.05 respectively, and Niger the lowest value of 814.86. On the other hand, with respect to the money supply/GDP ratio, Togo, Guinea-Bissau, and Senegal had the highest ratios with 55.58, 49.55 and 48.42 respectively recorded in 2015 , while Niger had the lowest ratio with 9.0 achieved in 2002. On average over the period, Senegal and Togo had the highest values with 38.06 and 36.69 , respectively. The lowest average was obtained in Niger with 17.77.

With respect to domestic credit, CB, in relation to GDP, Togo and Senegal had the highest values, with 42 and 35.98 respectively in 2015. The lowest value was recorded in Guinea Bissau with 4.27 recorded in 2004. On average over the period, the lowest ratio was also noted in Guinea Bissau with 9.41. For the same indicator, Senegal and Togo also obtained the highest average ratios with 26.74 and 26.57 , respectively. 
Table 2. Ratios of domestic bank credit to GDP and domestic credit granted to the private sector to GDP in WAEMU countries (2002-2015)

\begin{tabular}{ccccccc}
\hline \multirow{2}{*}{ Countries } & \multicolumn{3}{c}{ CB/GDP } & \multicolumn{3}{c}{ CP/GDP } \\
\cline { 2 - 6 } & Minimum & Average & Maximum & Minimum & Average & Maximum \\
\hline Benin & 5.25 & 13.59 & 20.45 & 10.44 & 17.98 & 22.92 \\
Burkina Faso & 12.43 & 17.26 & 29.30 & 13.38 & 18.65 & 28.90 \\
Ivory Coast & 16.88 & 21.76 & 31.48 & 12.23 & 15.98 & 23.77 \\
Guinea Bissau & 4.27 & 9.41 & 19.90 & 0.80 & 5.61 & 13.12 \\
Mali & 9.42 & 14.27 & 21.94 & 14.64 & 16.99 & 22.55 \\
Niger & 6.11 & 10.56 & 16.33 & 5.01 & 10.12 & 15.36 \\
Senegal & 20.76 & 26.74 & 35.98 & 18.50 & 25.19 & 33.56 \\
Togo & 15.96 & 26.57 & 42.00 & 12.45 & 22.64 & 37.42 \\
WAEMU & 4.27 & 17.52 & 42.00 & 0.80 & 16.65 & 37.42 \\
\hline
\end{tabular}

Source: Authors' calculations based on World Bank data, 2017.

For the ratio of domestic credit granted to the private sector, CP, relative to GDP, Togo and Senegal recorded the highest values with 37.42 and 33.56 respectively achieved in 2015. The lowest values were recorded in Guinea Bissau and Niger with 0.8 recorded in 2004 and 5.01 achieved in 2002, respectively. On average over the period, Senegal and Togo also obtained the highest figures with 25.19 and 22.64, respectively. Guinea Bissau and Niger also recorded the lowest averages with 5.61 and 10.12, respectively.

Table 3. Inflation rates and claims on the central government as a percentage of GDP in WAEMU Countries from 2002 to 2015

\begin{tabular}{ccccccc}
\hline \multirow{2}{*}{ Countries } & \multicolumn{3}{c}{ TINF } & \multicolumn{3}{c}{ CG/GDP } \\
\cline { 2 - 7 } & Minimum & Average & Maximum & Minimum & Average & Maximum \\
\hline Benin & -0.25 & 2.43 & 7.70 & -10.68 & -5.03 & -2.57 \\
Burkina Faso & -3.07 & 2.00 & 7.64 & -4.50 & -1.64 & 0.82 \\
Ivory Coast & -2.89 & 2.89 & 8.50 & 3.28 & 5.72 & 8.89 \\
Guinea-Bissau & -5.01 & 2.28 & 14.03 & 0.36 & 4.57 & 15.36 \\
Mali & -7.59 & 3.11 & 12.15 & -5.97 & -2.43 & -0.15 \\
Niger & -0.34 & 2.85 & 7.35 & -4.74 & 0.03 & 5.47 \\
Senegal & -2.32 & 1.63 & 6.90 & -0.70 & 1.30 & 3.53 \\
Togo & -9.82 & 2.42 & 14.58 & 0.16 & 2.33 & 5.36 \\
WAEMU & -9.82 & 2.45 & 14.58 & -10.68 & 0.61 & 15.36 \\
\hline
\end{tabular}

Source: Authors' calculations based on World Bank data, 2017.

During the study period, we noted that on average the inflation rate, TINF, was relatively low and was in the range of 2 to $4 \%$ for the 8 WAEMU countries where an average inflation rate of $2.45 \%$ was recorded. We also note periods of significant deflation recorded in Mali and Togo, as well as significant inflation recorded in Togo, Mali, and Guinea-Bissau.

With regards to claims on the government, CG, the results show that Côte d'Ivoire and Guinea Bissau obtained the highest amounts in relation to GDP over the entire period, with 8.89 recorded in 2014 and 15.36 in 2015 , respectively. The lowest ratio was obtained in Benin with -10.68 in 2007. On average, Ivory Coast recorded the highest ratio with 5.72 and Benin the lowest with -5.03 .

Table 4. Quality of regulation and compliance with laws in WAEMU Countries from 2002-2015

\begin{tabular}{|c|c|c|c|c|c|c|}
\hline \multirow{2}{*}{ Countries } & \multicolumn{3}{|c|}{ QR } & \multicolumn{3}{|c|}{$\mathrm{RL}$} \\
\hline & Minimum & Average & Maximum & Minimum & Average & Maximum \\
\hline Benin & -0.57 & -0.45 & -0.32 & -0.71 & -0.59 & -0.34 \\
\hline Burkina Faso & -0.42 & -0.25 & -0.09 & -0.68 & -0.46 & -0.18 \\
\hline Ivory Coast & -0.96 & -0.81 & -0.45 & -1.53 & -1.25 & -0.61 \\
\hline Guinea Bissau & -1.26 & -1.13 & -0.86 & -1.60 & -1.35 & -1.18 \\
\hline Mali & -0.59 & -0.47 & -0.34 & -0.76 & -0.42 & -0.03 \\
\hline Niger & -0.73 & -0.57 & -0.42 & -0.80 & -0.66 & -0.39 \\
\hline Senegal & -0.34 & -0.24 & -0.05 & -0.48 & -0.23 & 0.04 \\
\hline Togo & -1.00 & -0.86 & -0.70 & -1.13 & -0.94 & -0.79 \\
\hline WAEMU & -1.26 & -0.60 & -0.05 & -1.60 & -0.74 & 0.04 \\
\hline
\end{tabular}

Source: Authors' calculations based on World Bank data, 2017. 
During the study period, the institutional variables showed a somewhat weak regulatory environment with negative indices close to the lower limit set at -2.5 , which refers to a very weak institutional situation, and 2.5 in the case of a strong institutional presence. On average in the Union, the regulatory quality index was -0.60 , and -0.74 in terms of agents' compliance with the law, RL. The countries of Guinea-Bissau and Ivory Coast had the lowest levels of regulation and compliance by agents in the Union.

Table 5. Descriptive statistics for the panel variables

\begin{tabular}{lcccccrrr}
\hline & LY & LM2 & LCB & LCP & CG & TINF & QR & RL \\
\hline Mean & 7.348746 & 3.335839 & 2.770416 & 2.675792 & 0.853966 & 2.906401 & -0.586627 & -0.722306 \\
Median & 7.384265 & 3.335819 & 2.841388 & 2.827155 & 0.374579 & 2.859744 & -0.509251 & -0.651687 \\
Maximum & 8.101700 & 4.017761 & 3.737724 & 3.622290 & 15.35962 & 14.58089 & -0.046416 & 0.038312 \\
Minimum & 6.639975 & 2.196769 & 1.451285 & -0.220303 & -10.67569 & -9.823833 & -1.256410 & -1.599402 \\
Std. Dev. & 0.357612 & 0.340991 & 0.506616 & 0.699139 & 4.006363 & 3.859044 & 0.311474 & 0.416187 \\
Skewness & -0.138615 & -0.597908 & -0.443521 & -2.216266 & 0.318312 & 0.150119 & -0.389182 & -0.362490 \\
Kurtosis & 2.507126 & 3.509864 & 2.825042 & 8.763227 & 3.717231 & 4.522351 & 2.151724 & 2.210088 \\
Jarque-Bera & 1.492311 & 7.886375 & 3.814781 & 246.6900 & 4.291982 & 11.23590 & 6.185313 & 5.364606 \\
Probability & 0.474186 & 0.019386 & 0.148467 & 0.000000 & 0.116952 & 0.003632 & 0.045381 & 0.068405 \\
Sum & 823.0596 & 373.6140 & 310.2865 & 299.6887 & 95.64421 & 325.5169 & -65.70222 & -80.89833 \\
Sum Sq. Dev. & 14.19541 & 12.90654 & 28.48919 & 54.25624 & 1781.655 & 1653.037 & 10.76879 & 19.22645 \\
Observations & 112 & 112 & 112 & 112 & 112 & 112 & 112 & 112 \\
\hline
\end{tabular}

Source. Authors' calculations based on World Bank data, 2017.

The Country Panel study showed that on average GDP/capita growth for all the WAEMU countries was estimated at $7.34 \%$. With regards to financial development indicators, namely the ratio of money supply to GDP, the ratio of domestic bank credit to GDP, and the ratio of domestic credit granted to the private sector to GDP, the averages for the area studied were 3.33, 2.77 and 2.67, respectively. In addition, for the inflation rate and government-to-GDP variables, they average were 2.9 percent and 0.85 percent, respectively. As for the institutional framework variables, the data showed average scores of -0.58 for QR and -0.72 for RL. Scores close to 2.5 reflect better quality institutions. The average values recorded by the countries in the area show the need to improve the quality of institutional governance by the governments.

Table 6. Correlation between variables

\begin{tabular}{|c|c|c|c|c|c|c|c|c|}
\hline & LY & LM2 & LCB & LCP & $\mathrm{CG}$ & TINF & $\mathrm{QR}$ & RL \\
\hline LY & 1 & & & & & & & \\
\hline LM2 & 0.477 & 1 & & & & & & \\
\hline LCB & 0.455 & 0.770 & 1 & & & & & \\
\hline LCP & 0.378 & 0.674 & 0.803 & 1 & & & & \\
\hline $\mathrm{CG}$ & 0.141 & 0.146 & 0.288 & -0.234 & 1 & & & \\
\hline TINF & -0.007 & 0.021 & -0.030 & 0.037 & -0.002 & 1 & & \\
\hline QR & 0.139 & -0.002 & 0.209 & 0.471 & -0.547 & -0.046 & 1 & \\
\hline RL & 0.004 & 0.060 & 0.170 & 0.433 & -0.545 & -0.033 & 0.855 & 1 \\
\hline
\end{tabular}

Source: Authors' calculations based on World Bank data, 2017.

Table 6 shows, on the one hand, a positive correlation between the institutional framework variables and the financial development variables except for the one between QR and LM2 and, on the other hand, a positive correlation between the financial development variables and economic growth. However, it should be noted that there is also a positive relationship between the institutional variables and economic growth. 


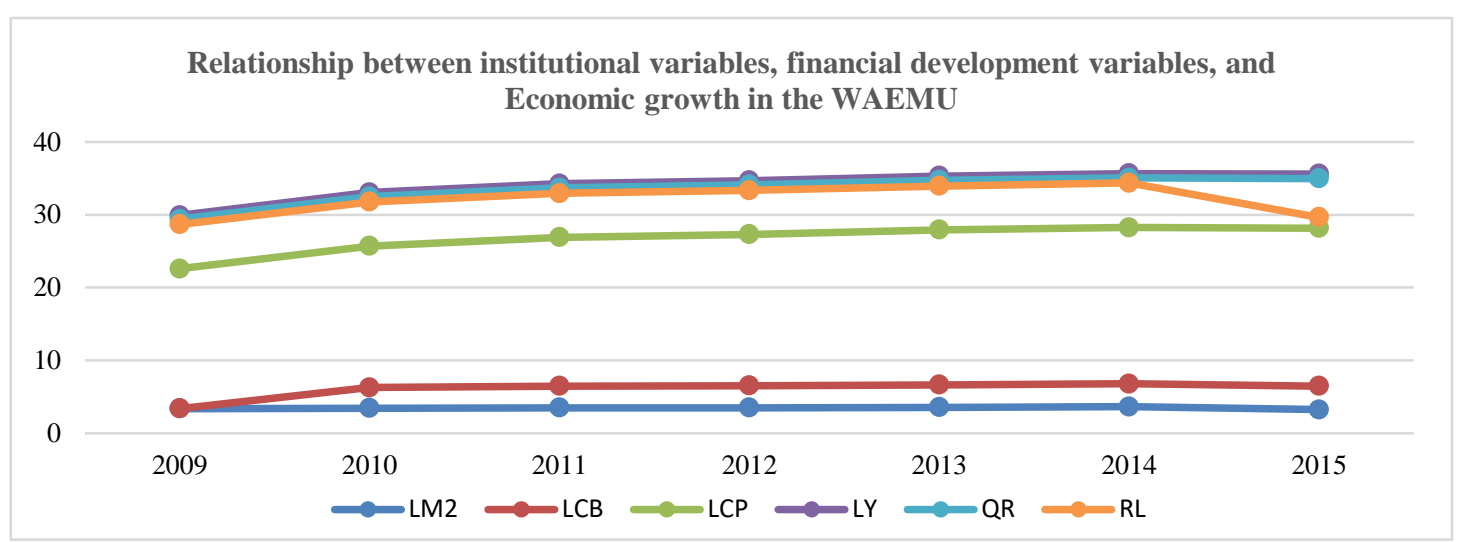

Figure 1. Changes in the relationship between institutional variables, financial development variables and economic growth in the WAEMU from 2009 to 2015

Source: Authors based on the World Bank data of 2017.

Figure 1 further illustrates the growing relationship between institutional variables and economic growth in the WAEMU countries. It also shows the positive relationship between financial development and institutional framework variables. Institutional quality seems to further enhance the effect of financial development on economic growth in this area.

\subsection{Econometric Estimates and Results}

\subsubsection{Analysis of the Series' Stationarity}

Given that most macroeconomic series are not stationary in practice, precautions must be taken before choosing which estimator to use. In this work, we work with panel data which are, indeed, of greater interest in determining the non-stationarity of variables. The use of panel data makes it possible to have more powerful stationarity tests because they allow us to work with small sample sizes in the time dimension by increasing the number of data available in the individual dimension, thus reducing the risk of structural breaks, and overcoming the problem of the low strength of small sample tests. However, an additional question arises in the search for the unit root when one is in a panel. What comes to mind is the uniqueness of a model to test for the presence of a unit root in the dynamics of a variable over several individuals. If so, this implies the existence of strictly identical dynamic properties for the variable whatever the country under consideration, which leads to the assumption of a homogeneous panel. Finding this restrictive hypothesis and potentially leading to spurious regressions in cases where the dynamics of the phenomenon studied may not be identical in different countries, we will use tests which take into accounts the heterogeneity of the panel and which capture some particularities specific to individuals. Thus, we will use two types of stationarity test specification, that of Levin, Lin, and Chu (2002) which postulates panel homogeneity and looks for the presence of a unit root common to the panel under consideration, and the test of Im Pesaran and Shin IPS (2003) which, in addition to accepting the alternative hypothesis of unit root heterogeneity, allows for heterogeneity with respect to the very presence of a unit root in the panel, as well as Fisher's PP-Fisher test. Table 6 below shows the results of the stationarity test and the three tests used.

Table 6. Stationarity tests on sample variables

\begin{tabular}{|c|c|c|c|c|c|c|}
\hline \multirow{2}{*}{$\begin{array}{c}\text { Variables } \\
\text { Unit root test } \\
\end{array}$} & \multicolumn{3}{|c|}{ Level stationarity } & \multicolumn{3}{|c|}{ Stationarity in first difference } \\
\hline & LL\&C & IPS & $\mathrm{PP}$ & LL\&C & IPS & $\mathrm{PP}$ \\
\hline GDP/capita & -1.930 & 0.234 & 14.943 & $-9.122^{* * *}$ & $-4.483^{* * *}$ & $66.906^{* * *}$ \\
\hline $\mathrm{M} 2 / \mathrm{GDP}$ & $-17.779^{* * *}$ & $-9.929^{* * * *}$ & $62.768^{* * *}$ & & & \\
\hline $\mathrm{CB} / \mathrm{GDP}$ & -1.529 & 0.057 & 31.260 & $-9.162^{* * *}$ & $-5.156^{* * *}$ & $66.488^{* * *}$ \\
\hline $\mathrm{CP} / \mathrm{GDP}$ & 1.971 & 2.069 & 8.291 & $-11.455^{* * *}$ & $-9.121^{* * *}$ & $80.169^{* * * *}$ \\
\hline CG/GDP & -1.176 & 1.102 & 9.531 & $-5.232^{* * *}$ & $-2.792^{* * *}$ & $54.016^{* * *}$ \\
\hline Inflation rate & $-5.711^{* * *}$ & $-2.999^{* * *}$ & $41.684^{* * *}$ & & & \\
\hline Quality of regulation & $-4.185^{* * *}$ & -0.985 & 23.356 & $-8.789^{* * *}$ & $-6.912^{* * *}$ & $111.65^{* * *}$ \\
\hline Campliance with laws & $-3.363^{* * *}$ & $-1.769^{* *}$ & 21.124 & $-7.096^{* * *}$ & $-4.824^{* * * *}$ & $68.186^{* * *}$ \\
\hline
\end{tabular}

Note. $* *, * * *$ refers to a significance of $5 \%$ and $1 \%$ respectively. 
The results on stationarity show that the variables GDP/capita, domestic bank credit/GDP, domestic credit to the private sector/GDP, debt to government/GDP, quality of regulation, and compliance with laws were first difference stationary. For the variables money supply M2/GDP and the inflation rate, there was a level stationarity. Thus, the application of the FMOLS method is possible because at the level of the explanatory variables we have at least one integrated variable of order 1 I (1); in our case, three variables were I (1).

\subsubsection{Econometric Estimation}

The OLS estimator is inconsistent and asymptotically biased in the case of cointegration on panel data and would not solve the possible problems of endogeneity bias that regressors may have. For this reason, we use the Fully Modified Ordinary Least Square or Modified Least Squares (FMOLS) estimator developed by Pedroni (2002). Initially proposed by Phillips and Hansen (1990) and extended by Phillips (1995), it consists of a semi-parametric procedure for estimating the parameters of a cointegrating relationship that allows the correction of the long-term endogeneity bias.

Fully Modified consists simply in applying OLS to a transformed model; with the transformation used being obtained from a convergent estimator of the long-term variance-covariance matrix of the residuals and innovations of the non-stationary variables. Thus, the estimation of equation 2 below by Modified Least Squares provided us with the results confined in Table 7 below:

$$
\ln y_{i t}=\alpha_{0}+\alpha_{1} L M 2_{i t}+\alpha_{2} L C B_{i t}+\alpha_{3} L C P_{i t}+\alpha_{4} C G_{i t}+\alpha_{5} T I N F_{i t}+\alpha_{6} L Q R_{i t}+\alpha_{7} L R L_{i t}+\varepsilon_{i t}
$$

Table 7. Results of the estimation by the FMOLS method

\begin{tabular}{ccccc}
\hline Variable & Coefficient & Std. Error & t-Statistic & Prob. \\
\hline LM2 & 0.113777 & 0.055123 & 2.064050 & $0.0419^{* *}$ \\
LCB & 0.139397 & 0.045645 & 3.053963 & $0.0030^{* * * *}$ \\
LCP & -0.037853 & 0.031126 & -1.216124 & 0.2272 \\
TINF & -0.000735 & 0.001385 & -0.530480 & 0.5971 \\
LCG & -0.010015 & 0.003909 & -2.562178 & $0.0121^{* *}$ \\
LQR & 0.117208 & 0.061991 & 1.890734 & $0.0619^{*}$ \\
LRL & 0.037814 & 0.038032 & 0.994265 & 0.3228 \\
\hline R-squared & 0.987901 & Mean dependent var & 7.353991 \\
Adjusted R-squared & 0.985997 & S.D. dependent var & 0.356583 \\
S.E. of regression & 0.042196 & Sum squared resid & 0.158462 \\
\hline
\end{tabular}

Note. $* * *, * * *$ represent a significance of $10 \%, 5 \%$ and $1 \%$ respectively.

\subsubsection{Interpretation of Results}

The results show that money supply relative to GDP (LM2/GDP), domestic bank credit relative to GDP (LCB) and regulatory quality (QR) have a positive and significant impact on GDP per capita (Ly) in the long run. The positive and significant relationship of regulatory quality $(\mathrm{RQ})$ on economic growth could be explained, in the long run, by the positive effect of RQ on financial development. This result is consistent with those found by Diandy (2018), Barajas et al. (2013) and Kos et al. (2016). As for the positive relationship between domestic bank credit to GDP and economic growth, it could be explained by the investment channel. Indeed, domestic credit increases the amount of investment and capital accumulation, which in turn increases productivity and growth.

As for the negative and insignificant relationship between inflation and economic growth, it would be linked to the deterioration of financial depth. Moreover, research has shown that the relationship between inflation and growth is not linear, and low inflation rates have a positive influence on growth. Bruno and Easterly (1998) showed that the negative relationship between inflation and growth is due to episodes of high inflation.

On the other hand, debts to government (cg) have a significant and negative influence on real GDP/capita. This result could be explained, on the one hand, by the fact that a large part of these receivables is used to finance operating and social expenditures and only the leftover is allocated to investment. However, Gemmell, Kneller, and Sanz (2015) focused on a panel of seventeen OECD countries from 1972 to 2008 using the Pooled Mean Group (PMG) method of Pesaran, Shin, and Smith (1999). They found that a reallocation of public spending towards education and infrastructure spending had a positive impact on the level of long-term production. On the other hand, a reallocation of public spending towards welfare spending is associated with modest negative 
effects on long-term output. On the other hand, governments are led to increase the tax rate following borrowing to be able to finance public spending. In addition, the literature has shown that a positive tax shock would have negative long-term effects on economic growth. For example, Blanchard and Perroti (2002) concluded that a positive shock in public spending had a favorable effect on economic activity. On the other hand, a positive tax shock (increase) has negative effects on output. On the other hand, a simultaneous increase in public spending and taxes negatively and significantly affects private investment. This last result reinforces the one found in this article.

\section{Conclusion and Economic Policy Implications}

This paper examined the impact of financial development and the institutional environment on economic growth in the WAEMU countries. A standard growth model was used, following the example of Eggoh (2010) with a panel data cointegration technique. We used the World Bank's 2017 database (World Bank data, 2017).

The results showed that the financial development variables, namely money supply relative to GDP (LM2/GDP) and domestic bank credit relative to GDP (LCB), have a positive and significant impact on GDP per capita (Ly) in the long run. The institutional variable regulatory quality (RQ) had a significant and positive influence on economic growth in the WAEMU zone. The negative and insignificant relationship between inflation and economic growth would be linked to the deterioration of financial depth.

Three economic policy implications ensue from these results. The first highlights the role that the banking system should play in facilitating access to financing. Banks must find flexible ways of accessing credit with sustainable interest rates that can propel investment and the profitability of economic agents' activities. The second implication emphasizes the need to focus more on strengthening the regulation quality by governments. Indeed, compliance with law and order has a positive but insignificant impact on economic growth. The third implication concerns the role that the states in the union must play to control the level of inflation in a sustainable manner. This implication is even more interesting since private domestic credit in the presence of high inflation has a negative impact on economic growth over time.

The main limitation of this work was the absence of an indicator that would make it possible to gauge the weight and importance of the financial market on the Union's economic growth. This was linked to the fact that the WAEMU financial market is relatively underused; and to the difficulties we experienced in obtaining data applicable to this work over a desirable time horizon. In terms of prospects, it would be interesting to have a variable to measure the effect of the financial market to be able to explain the importance of the financial structure, in general, on economic growth in the presence of a favorable institutional environment the in WAEMU.

\section{References}

Acemoglu, D., \& Zilibotti, F. (1997). Was Prometheus Unbound by Chance? Risk, Diversification and Growth. Journal of Political Economy, 105, 709-775. https://doi.org/10.1086/262091

Afi, E., \& Komlan, F. (2019). Finance, Institutions, Remittances and Economic growth: New Evidence from a Dynamic Panel Threshold Analysis. Journal of Applied Finance and Banking, 9(2), 69-104.

B.E, H., \& P. C. B. P. (1990). Estimation and Inference in Models of Cointegration: A Simulation Study. Advances in Econometrics, 8, 225-248. https://doi.org/10.1007/978-1-349-20570-7_30

Beck, T., Demirguç-Kunt, A., \& Levine, R. (2000). A new database on financial development and structure. World Bank Economic Review, 14, 597-605. https://doi.org/10.1093/wber/14.3.597

Benali, S. (2020). Système bancaire, Qualité des institutions et Croissance économique: Analyse en données de panel sur un échantillon de pays de la région MENA. Revue Française d'Economie et de Gestion, 1(5), $1-12$.

Bencivenga, V., \& Smith, B. (1991). Financial Intermediation and Endogenous Growth. Review of Economic Studies, 58, 195-209. https://doi.org/10.2307/2297964

Blackburn, K., \& Hung, V. (1998). A Theory of Growth, Financial Development and Trade. Economica, 65(257), 107-124. https://doi.org/10.1111/1468-0335.00116

Bruno, M., \& Easterly, W. (1998). Inflation crises and long-run growth. Journal of Monetary Economics, 41, 3-26. https://doi.org/10.1016/S0304-3932(97)00063-9

Deidda, L., \& Fattouh, B. (2002). Non-linearity between Finance and Growth. Economics Letters, 74, 339-345. https://doi.org/10.1016/S0165-1765(01)00571-7 
Deidda, L., \& Fattouh, B. (2008). Banks Financial Markets and Growth. Journal of Financial Intermediation, 17, 6-36. https://doi.org/10.1016/j.jfi.2006.04.003

Demetriades, P., \& Law, S. (2004). Finance, Institutions and Economic Growth. University of Leicester.

Diandy, I. (2018). Développement financier, institutions et croissance économique en Afrique Subsaharienne: Cointégration et causalité par les VAR en Panel. Finance et Finance Internationale, 10, 2-24. https://doi.org/10.12816/0045343

Ebo'Oh Ntjen, S. D., \& Neba, C. Y. (2021). Développement financier, institutions et croissance en Afrique au Sud du sahara. Revue Repères et Perspectives Economiques, 5(1), 405-423.

Eggoh, C. (2009). Croissance Economique et Développement Financier: Eléments d'analyse théorique et empirique (U. d'Orléans, Éd.). Université d'Orléans.

Eggoh, C., \& Villieu, P. (2010). Croissance, Intermédiation et Indétermination. Economies et Sociétés, 44(5), 795-828.

Gazdar, K. (2011). Institutions, développement financier et croissance économique dans la région MENA. Université de Reims-Marne.

Gemmel, N., \& Kneller, R. (2001). The Impact of Fiscal Policy on Long-Run Growth. European Economy, Reports and Studies, 1, 97-129.

Goldsmith, R. (1969). Financial Structure and Development. Yale University Press.

Gurley, J., \& Shaw, E. (1955). Financial aspects of economic development. American Economic Review, 45, 515-538.

Haslag, J., \& Koo, J. (1999). Financial repression, financial development and economic growth. Working Paper, Federal Reserve Bank of Dallas.

King, R. G. (1993). Finance, Entrepreneurship and Growth. Theory and Evidence, 32(b), 513-542. https://doi.org/10.1016/0304-3932(93)90028-E

King, R., \& Levine, R. (1993). Finance and growth: Schumpeter might be right. Le Journal Trimestriel D'ÉConomie, 108(3), 707-738. https://doi.org/10.2307/2118406

Kos, M., \& Kamajou, F. (2016). Déterminants Du Développement Financier Dans Les Pays De La Zone Franc CFA : Le Rôle De La Qualité Des Institutions. European Scientific Journal, 12(28), 285-311. https://doi.org/10.19044/esj.2016.v12n28p285

K-S, I., Pesaran, M. H., \& Shin, Y. (1997). Testing for Unit Roots in Heterogenous Panels. University of Cambridge. DAE.

K-S, I., Pesaran, M., \& Shin, Y. (2003). Testing for Unit Roots in Heterogeneous Panels. Journal of Econometrics, 115(1), 53-74. https://doi.org/10.1016/S0304-4076(03)00092-7

Levine, R. (2005). Finance and growth: theory and evidence. In P. Aghion \& S. Durlauf (Ed). Elsevier. https://doi.org/10.3386/w10766

Levine, R., \& Zervos, S. (1996). growth, Stock market development and long-run. World Bank Economic Review, 10, 323-339. https://doi.org/10.1093/wber/10.2.323

Maddala, G., \& Wu, S. (1999). A Comparative Study of Unit Root Tests and a New Simple Test. Oxford Bulletin of Economics and Statistics, 61(Special Issue), 631-652. https://doi.org/10.1111/1468-0084.0610s1631

McKinnon, R. I. (1973). Money and Capital in Economic Development. The Brookings Institution, Washington D.C.

Mubarik, Y. (2005). Inflation and Growth: An Estimate of the Threshold Level of Inflation in Pakistan. State Bank of Pakistan Research Bulletin, 1(1).

Muye, I., \& Muye, I. (2017). Testing for causality among globalization, institution and financial development: Further evidence from three economic blocs. Borsa Istanbul Review, 17(2), 117-132. https://doi.org/10.1016/j.bir.2016.10.001

Pagano, M. (1993). Financial Market and Growth: An Overview. European Economic Review, 37, 613-622. https://doi.org/10.1016/0014-2921(93)90051-B

Phillips, P. (1995). Fully Modified Least Squares and Vector Autoregression. Econometrica, 63(5), 1023-1078. https://doi.org/10.2307/2171721 
Rioja, F., \& Valev, N. (2004). Finance and the Sources of Growth at Various Stages of Economic development. Economic Inquiry, 42, 127-140. https://doi.org/10.1093/ei/cbh049

Robinson, J. (1952). The Rate of Interest and Other essays. Mcmillan, London.

Rousseau, P., \& Wachtel, P. (2002). Inflation thresholds and the finance-growth nexus. Journal of International Money and Finance, 21, 777-793. https://doi.org/10.1016/S0261-5606(02)00022-0

Samina, S. E. (2019). Financial development, Technology and economic development: The role of institutions in developing countries. Annals of financial Economics, 14(3), 1-25. https://doi.org/10.1142/S201049521950012X

Schumpeter, J. (1912). The Theory of Economic Development. Oxford University Press.

Sghaier, I. (2018). Financial Development, Institutions and Economic Growth in North African Countries. the Romanian Economic Journal, 69, 53-72.

\section{Copyrights}

Copyright for this article is retained by the author(s), with first publication rights granted to the journal.

This is an open-access article distributed under the terms and conditions of the Creative Commons Attribution license (http://creativecommons.org/licenses/by/4.0/). 